\title{
Erratum to: Potential Prognostic Significance of Patterns of Deletion (13q) in Plasma Cell Myelomas- Reappraisal of a Perennial Bone of Contention
}

\author{
Mohit Kumar Bhardwaj ${ }^{1 *}$ Sourav Kumar Mishra ${ }^{2 *}$ Shivani Sharma ${ }^{1} \quad$ Beklashwar Salona ${ }^{1}$ \\ Sambit Kumar Mohanty ${ }^{1,3}$
}

${ }^{1}$ Department of Pathology and Laboratory Medicine, CORE

Diagnostics, Gurgaon, Haryana, India

${ }^{2}$ Department of Medical Oncology, Advanced Medical Research Institute, Bhubaneswar, Odisha, India

${ }^{3}$ Department of Pathology and Laboratory Medicine, Advanced Medical Research Institute, Bhubaneswar, Odisha, India

\begin{abstract}
Address for correspondence Sambit Kumar Mohanty, MD, FIAC, FACP, FRCPath, Department of Oncologic and Molecular Pathology, Advanced Medical Research Institute, \#1, Besides Satyasai Enclave, Khandagiri, Bhubaneswar, Odisha 751030, India

(e-mail: sambit04@gmail.com).
\end{abstract}

Ind J Med Paediatr Oncol 2021;42:297-300.

\section{Erratum}

${ }^{*}$ MK and SKM share the first authorship.

DOI https://doi.org/ $10.1055 / s-0041-1741583$ ISSN 0971-5851
Publisher regrets to inform that two author names got missing in the list of authors in the above-mentioned article published in issue 42.3. The DOI of the original article is 10.1055/s-0041-1732852.

Two names, Dr Sourav Kumar Mishra and Dr Shivani Sharma, have been added to the list.
(C) 2021. Indian Society of Medical and Paediatric Oncology. This is an open access article published by Thieme under the terms of the Creative Commons Attribution-NonDerivative-NonCommercial-License, permitting copying and reproduction so long as the original work is given appropriate credit. Contents may not be used for commercial purposes, or adapted, remixed, transformed or built upon. (https://creativecommons.org/licenses/by-nc-nd/4.0/).

Thieme Medical and Scientific Publishers Private Ltd. A-12, Second Floor, Sector -2, NOIDA -201301, India 